IRSH 6I (20I6), pp. 35-50 doi: I0.10I7/So0208590I6000055

(C) 2016 Internationaal Instituut voor Sociale Geschiedenis

\title{
Facing Marxist Orthodoxy: Western Marxism, The Making, and the Communist Historiographies of Czechoslovakia and Poland, I948-1990*
}

\author{
RUDOLF K U ČERA \\ Institute of International Studies, \\ Faculty of Social Sciences, Charles University \\ $U$ Křže 8, is 8 oo Prague 5, Czech Republic \\ E-mail: r.kucera@email.cz
}

\begin{abstract}
Although the impact of Thompson's work outside the UK has been recognized and pointed to many times, the ways in which Thompsonian categories and concepts, or Marxist thought from the West more broadly, was received in the countries of the former Eastern Bloc remain rather unclear. Although The Making has never been translated into Polish, Czech, or Slovak, the historians of East-Central European countries were not totally cut off from Western scholarship. Major academic institutes and universities throughout the communist bloc maintained basic contacts with colleagues in the West, and Thompson's work was known among some local social historians. Marxism from the West in general and Thompson's work in particular posed challenges that had to be dealt with. This paper traces the ways in which historians of Poland and Czechoslovakia responded to these challenges to the official position of Marxist orthodoxy. Taking The Making as an example, it highlights the reception (or lack thereof) of Western influences on local scholarship, and the dynamics of these encounters - whether they were affirmative or critical - in relation to the changing political landscape of East-Central European countries after World War II.
\end{abstract}

\footnotetext{
* I wish to express my gratitude to Sven Beckert, Rudi Batzell, and Gabriel E. Winant, who commented on earlier versions of this article. I also wish to thank the participants in the conference "The Global E.P. Thompson" organized by Harvard University, especially Thomas Lindenberger and Charles Maier, for their valuable comments on the first draft, which I presented there. Valuable information and ideas were also provided by Maciej Górny and Vítězslav Sommer as well as by the anonymous reviewers. Finally, I wish to thank the Imre Kertész Kolleg at the University of Jena for providing such a fruitful intellectual environment, and the Faculty of Social Sciences at Charles University in Prague, which supported my research as part of its "Pi7 Sciences of Society, Politics, and Media under the Challenge of the Times" research programme.
} 
In the summer of 1948 , the inhabitants of the Austrian city of Salzburg might have seen some very unexpected encounters. In the still badly damaged town, which saw around forty per cent of its buildings destroyed or damaged during the US bombings in 1944, an academic summer school in American studies was organized by Harvard University. Teachers from the US, led by the renowned sociologist Talcott Parsons, lectured over I 70 doctoral candidates and young postdocs from all over Europe. For six weeks, young scholars from Germany, Austria, Italy, and England met with Poles, Czechs, and Hungarians, and listened to lectures on different topics from American culture, politics, and history.

Mutual contacts were forged, as well as closer, long-lasting transnational friendships. One of the participants in the summer school, Josef Polišenský, the thirty-two-year-old rising star of Czechoslovak historiography, noted in his memoirs that the most interesting person was "[...] the English historian [George Albert] Shepperson, Cambridge graduate [...] [and a] hard-line Marxist, disciple of Maurice Dobb, who significantly broadened my knowledge". Polišenský was not the only Czechoslovak participating in the conference. He was part of a group of six young Czechoslovak historians, literary scholars, and translators, whose travel and accommodation costs were paid for by the communist government of their home country, which had come to power after the political coup d'état only a few months earlier in February 1948. Polišenský and his fellow Czechoslovak academics were granted the opportunity to take part in constituting the international scholarly networks that started to emerge in the devastated postwar intellectual landscape of Europe; networks that, in many cases, transcended the political East-West division. Polišenský profited from these entanglements not only in terms of intellectual exchange; as he later conceded, without close ties to British Marxist historians he would never have discovered so early such products of Western popular culture as the Rolling Stones. ${ }^{2}$

Throughout the i950s and I960s, Polišenský and other selected members of East-Central European academia were able to sustain and broaden such networks. Although not entirely free to choose the venues for participating in the transnational exchange, and often under close observation by the state, some East-Central European scholars in the humanities were nevertheless able not only to maintain basic contacts with the West but also to import significant pieces of research and research methodologies, and to integrate them into local scholarship. ${ }^{3}$ However, such contacts and

I. Josef Polišenský, Historik v měnícím se světě [Historian in a Changing World] (Prague, 2001), pp. I 57-1 58. All translations from Czech and Polish are mine.

2. Ibid., p. 206.

3. See, for example, the overview of Czechoslovak participation at international congresses of historical sciences from the late nineteenth century: Bohumil Jiroušek (ed.), Czech and Czechoslovak Participation in International Congresses of Historical Sciences (České Budějovice, 2006). 
influences between the historiographies on both sides of the Iron Curtain have not sufficiently been tackled by recent research on the history of twentieth-century historiography. ${ }^{4}$ Many writings emphasize the Sovietization of university education and the subordination of research to a tight political and ideological policing by communist parties that brought about a rapid imposition of an entirely one-sided transfer of research methodologies, concepts, and practices from the Soviet Union. ${ }^{5}$ However, some recent studies have shown that this one-sided transfer was, in many cases, quite unsuccessful and that local historiographies were able to maintain significant, although varied, levels of autonomy. ${ }^{6}$ Nevertheless, the internal dynamic of development within the historiographies of the region is still seen in many cases as having been driven by either domestic forces in each respective country, or by transnational networks that were, however, only articulated within the spatial framework east of the Iron Curtain. Possible contacts with and influences from Western European historiographies constitute a field largely unexplored by scholars.

The following article endeavours to enter precisely into this terrain. By examining the reception that Thompson's seminal book on labour history, The Making of the English Working Class, had in the official historiographies of two countries of the East, Czechoslovakia and Poland, it attempts to shed light on possible contacts and influences transmitted across the Iron Curtain from the West to the East. ${ }^{7}$ However, in order to

4. See, most recently, Daniel Woolf, A Global History of History (Cambridge, 20I I), pp. 472-483. Georg G. Iggers and Q. Edward Wang, A Global History of Modern Historiography (Harlow, 2008), pp. 250-316. Georg Iggers, it should be noted, has highlighted East-West contacts, especially between the two Germanys, in several of his older publications and has himself been a medium of such exchanges.

5. See, for example, Eva Schmidt-Hartmann, "Forty Years of Historiography under Socialism in Czechoslovakia", Bohemia, 2 (1988), pp. 300-324. Ilko-Sascha Kowalczuk, Legitimation eines neuen Staates. Parteiarbeiter an der historischen Front. Geschichtswissenschaft in der SBZ/DDR I945-I96I (Berlin, 1997). For a critical engagement with the Sovietization concept, see John Connelly, Captive University: The Sovietization of East German, Czech, and Polish Higher Education, 1945-1956 (Chapel Hill, 2000).

6. See, most recently, Maciej Górny, Die Wabrheit ist auf unserer Seite. Nation, Marxismus und Geschichte im Ostblock (Cologne and Vienna, 20 I I). Pavel Kolár, "Rewriting National History in Post-War Central Europe: Marxist Syntheses of Austrian and Czechoslovak History as New National Master Narratives", in Stefan Berger and Chris Lorenz (eds), Nationalizing the Past: Historians as Nation Builders in Modern Europe (Basingstoke, 2010), pp. 319-340.

7. Of course, the reception given to E.P. Thompson in other East-Central European countries would merit further study as it might have varied considerably from the two cases chosen here. Particularly special conditions existed, for instance, in the GDR, where such processes of transfer were framed not only by the East-West divide but also by the intra-German one as labour history constituted an important field of research on both "sides". For more details, particularly on the West German reception to E.P. Thompson, see Thomas Lindenberger's article "From Structuralism to Culturalism: The Protracted German Reception of The Making of the English Working Class and its Actuality Reassessed from a Post-Cold War Perspective" in 61:I of this journal. 
understand the varied reception The Making had in the countries of the region, the article will also put it into the wider frame of the East-West scholarly contacts forged immediately after World War II. In adopting this larger framing, the article will examine some of the major works on nineteenth-century labour history that were produced by Czechoslovak and Polish historians after World War II. as well as the leading scholarly journals that were published as major platforms of their respective national historiographies. Here, references to Thompson's work as well as to some other seminal works of Western Marxist historiography will be traced, as will the ways in which Thompson and other Marxists from the West were accommodated into prevailing local narratives. Given the transnational scope and the lack of existing knowledge about the reception of Western labour history in East-Central Europe, the article tries to provide at least a basic and introductory overview of orthodox Marxism's reaction to one of the main works of Western leftist thought.

\section{COMMUNIST INTERNATIONALISM OF THE $1950 \mathrm{~s}$ \\ AND EARLY $1960 \mathrm{~s}$}

It is not surprising that Czechoslovak and Polish historians looked for scholarly interlocutors within the broad milieu of West European Marxist historiography, predominantly in Great Britain and France. From as early as 1950, for example, one of the most prominent topics of Czechoslovak historiography in subsequent years - research on the Hussite rebellion during the first half of the fifteenth century - developed under the strong influence of British Marxist historiography. As Polišenský recalls in his memoirs: "In 1950, I got an invitation to the International Congress of Historical Sciences, which was to be held in Paris for the first time. In the end, the ministry responsible chose Václav Husa, who brought me back a book on the crisis of feudalism in the fourteenth century by my friend Rodney Hilton from Birmingham." ${ }^{8}$ Polišenský, who was not a scholar of the medieval period, subsequently passed this book on to his colleagues Josef Macek and František Graus, who both incorporated the main theses of Hilton's writings into their own works on the Hussite rebellion and the general history of feudalism, which constituted one of the most seminal and influential fields of historical writings in I950s Czechoslovakia. ${ }^{9}$

8. Polišenský, Historik, pp. I68-169. The book mentioned was Rodney Hilton, The Economic Development of some Leicestershire Estates in the Fourteenth and Fifteenth Centuries (Oxford, 1947). Polišenský not only had close contacts with Rodney Hilton, he was well-networked in the UK in general.

9. See, for example, Josef Macek, Tábor v husitském revolučním hnutí, vols I-II. [Tábor in the Hussite Revolutionary Movement, 2 vols] (Prague, 1952-1955). František Graus, Dějiny venkovskébo lidu v Čechách v době predhusitské. Od poloviny I3. stol. do roku I4I9 [History of the 
Czechoslovak communist historiography's main point of contact with Western scholarship in the I950s was the British circle of communist historians formed around Rodney Hilton, Christopher Hill, and Eric Hobsbawm. ${ }^{10}$ Many books written by British Marxists were reviewed or noted in the main journal of Czechoslovak historical writing, the Československý časopis historický [Czechoslovak Historical Review], ${ }^{\mathrm{II}}$ and some of them were even translated into Czech or Slovak. ${ }^{\mathrm{I}}$ Thus, for example, a Czech translation of The English Rising of I38I by Rodney Hilton and Hyman Fagan appeared in 1952, only two years after the publication of the original, and was supplemented by a new introduction, written by the authors specially for Czech and Slovak readers. The close connections between British Marxist historians and Czechoslovakia were explicitly acknowledged by Hilton and Fagan in their introduction:

Nowadays English workers and intellectuals are finding great inspiration in the Czechoslovak effort to build socialism - inspiration for their own struggle for emancipation and peace. British Marxists, coming to Czechoslovakia, are realizing that they think in the same way as their Czech and Slovak comrades. [...] Those of us who had the luck to exchange experiences with Czech and Slovak Marxists are eager to continue in this collaboration. This book constitutes just a small contribution from the British side, with the aim to encourage such cooperation. ${ }^{\mathrm{I}}$

Czechoslovak historiography was probably the one most connected to, and influenced by, the British Marxist circle in East-Central Europe. After all, the main flagship of British Marxist history, the journal Past $\mathcal{E}$ Present, featured Josef Polišenský as one of the "international advisers" to the editorial board. As is well known, Polish historiography was more interested in French scholarship than English-speaking Marxists. Maintaining traditionally close

Rural People in Bohemia in the Pre-Hussite Era: From the Mid-Thirteenth Century to I4I9] (Prague, 1957). Josef Macek in particular embodied the new historiography of communist Czechoslovakia. Besides his many influential writings, he also served as the principal adviser to the monumental movie trilogy about the Hussite rebellion, which was produced between 1954 and 1957 .

I0. For the particular example of Hobsbawm's lively contacts with the communist countries of East-Central Europe, see his memoirs, Eric J. Hobsbawm, Interesting Times: A Twentieth Century Life (New York, 2002), pp. I76-177, 200-201.

I I. For a basic overview of the most prominent East-Central European historical journals, see Frank Hadler, "Századok - Kwartalnik Historyczny - Český časopis historický. Drei konstanten Ostmitteleuropäischer Historiographie”, in Matthias Middell (ed.), Historische Zeitschriften im internationalen Vergleich (Leipzig, 1999), pp. I45-1 59.

I2. See, for example, an unauthored review article on the newest British literature on labour history, Československý časopis historický, 4 (1953), pp. 565-567. Academic literature was generally translated into Czech in post-1945 Czechoslovakia. However, this was not a rigid rule and some publications were also, or only, translated into Slovak.

I3. Rodney Hilton and Hyman Fagan, Anglické povstání roku 138 I [The English Rising of I 38 I] (Prague, 1952), pp. 3-4. 
ties with French academia, Polish historians in the I950s and I960s entered into an intensive dialogue about the interpretation of the French Revolution. ${ }^{4}$ The recent writings of the French Marxists, particularly those by Albert Soboul, were closely surveyed and discussed. Polish relationships to the French revolutionary regime were sought, and Polish historians generally welcomed the systematic and straightforward class analysis of the causes and course of French history at the end of the eighteenth century. ${ }^{\text {Is }}$ Soboul's works, in particular, were praised as "[...] a model of historiographical clarity", ${ }^{16}$ and translations of his shorter journal articles repeatedly appeared in the pages of central Polish scholarly journals. ${ }^{17}$

However, as Polish historiography was probably the most open and receptive towards Western scholarship, British Marxist writings were also well known among Polish historians. In fact, it was Polish scholarship that was the first to go beyond a mere acknowledgement and start to critically engage with British writings. For instance, in 1963, Eric Hobsbawm's The Age of Revolution, published the year before, sparked some critical remarks by Polish historians. While Hobsbawm's Marxist approach, as well as his extraordinarily wide geographical span, was generally praised across East-Central Europe ${ }^{18}$ Polish historians questioned the book from a conceptual standpoint. Deploying what was later to become one of the main starting points of the postcolonial critique of the Atlantic historiographical tradition, Polish reviewers heavily criticized what they called the book's "Anglo-French" perspective, manifested in the depiction of European development in the first half of the nineteenth century as driven by the English industrial and French political revolutions. Regions east of the Rhine thus appeared, according to the critique, as merely passive objects reacting to the economic, social, and political dynamics brought to them from England and France. ${ }^{19}$

In sum, in the I950s and early I960s, the historiographies of Czechoslovakia and Poland were clearly not cut off from Western scholarship. Seminal works of British and French historians were

I4. Maciej Górny, The Nation Should Come First: Marxism and Historiography in East Central Europe (Frankfurt am Main, 2013), pp. 259-260.

I s. See, for example, the extensive review article on recent French scholarship dealing with the French Revolution: Andrej Zahorski, "Trzy Syntezy Wielkej Rewolucji Fracuskiej” [Three Overviews of the French Revolution], Przeglad Historyczny, I (1964), pp. 22-45.

16. Idem, Review of Albert Soboul's Précis d'bistoire de la Révolution Française (Paris, 1962) and La Révolution Française (Paris, 1965), Kwartalnik Historyczny, 4 (1965), pp. 979-980.

17. See, for example, Albert Soboul, "Opis i Miara W Historii Spolecznej" [Description and Measurement in Social History], Kwartalnik Historyczny, 2 (1966), pp. 277-290.

18. See, for a typical example, the following unauthored review of Hobsbawm's The Age of Revolution (London, I962), Československý časopis historický, s (1963), p. 705.

19. See, for instance, Jerzy Jedlicki's review of Eric J. Hobsbawm's The Age of Revolution: Europe 1789-1848 (London, I962), Kwartalnik Historyczny, I (1966), pp. 195-I98. 
registered, read, and discussed, and some of their arguments even found their way into local writings. It is not surprising, then, that when, in 1963 , as Eric Hobsbawm recalled, E.P. Thompson's “[...] erupting volcano of 848 pages [exploded]", ${ }^{\circ}$ this volcano's blaze was spotted even behind the Iron Curtain. However, if we look more closely at the reactions to Thompson's major piece, it appears that this blaze shone differently in each of the countries, and generally more dimly than in some other parts of the world.

\section{SPOTTING THE VOLCANO: RECEPTION OF THE MAKING IN THE $1960 \mathrm{~s}$}

The Czechoslovak scholarly community, at least in all printed publications, effectively ignored The Making throughout the whole of the I96os. Not a single review, discussion, or even a footnote found its way into the major scholarly journals or monographs on modern labour history. When, for example, in I 966, one of the leading Czech labour historians, Arnošt Klíma, was selected by the Czechoslovak Academy of Sciences to represent Czechoslovak historiography at the International Congress of Social and Economic History in West Berlin, he delivered a lecture entitled "The Formation of the Working Class and the Beginnings of the Labour Movement in Bohemia". ${ }^{2 \mathrm{I}}$ In front of an international audience, Klíma reviewed the recent trends in Czechoslovak labour history, spoke about the leading role of the textile industry, the foundations of the first large industrial enterprises, and about the formation of the Czech organized working class, which, according to him and to the widely shared Czechoslovak consensus, emerged as an objective phenomenon, stemming from the dialectics of industrialization. In what was supposed to be a showcase of "best practice" Czechoslovak historiography of the mid-r960s, presenting the most recent developments in the field, Thompson remained entirely absent. While generally giving credit to the works of British labour historians, particularly Eric Hobsbawm, ${ }^{22}$ Czechoslovak historians consistently ignored The Making and its conceptual challenges.

This absence is surprising given that Thompson's magnum opus was published in a period of relative liberalization, when significant shifts were

20. Hobsbawm, Interesting Times, p. 2 I4.

21. Arnošt Klíma, Die Entstehung der Arbeiterklasse und die Anfänge der Arbeiterbewegung in Böhmen. Sonderdruck aus "Wirtschafts- und Sozialgeschichtliche Probleme der frühen Industrialisierung” (Berlin, 1967).

22. See, for just one example of the numerous references to and annotations of Hobsbawm's work, the acknowledgment by an influential Czechoslovak historian of industrialization, Jaroslav Purš, [discussion of Eric Hobsbawm, The Age of Revolution], Československý časopis historický, 5 (1963), p. 705. 
emerging within the intellectual landscape of the Czechoslovak humanities in general and historiography in particular. ${ }^{23}$ Moreover, a second, revised edition of The Making was published by Penguin books in 1968 at the peak of the Prague Spring reform movement, and in the general context of the Czechoslovak intellectual and political thaw of the late i96os. Younger historians, who had completed their studies after the war, were raising their voices in Czechoslovakia, refusing to follow uncritically the model of the older generation. There was criticism of the official version of Marxism, which tried only to adhere to the prefabricated interpretations forged not in the field of history but by ideological party apparatchiks. ${ }^{24}$ Already in the first half of the I960s, a new generation of scholars had set out in search of a new comprehensive narrative of Czechoslovak history. ${ }^{25}$ Subsequently, in the second part of the 1960s, Czechoslovak historians reformulated almost all the previous standpoints of the orthodox Marxists, and forged a complex historical narrative of the "specific Czechoslovak way to socialism". This new interpretation served as the historiographical reference point of the Prague Spring reform movement. ${ }^{26}$

This shift within Czechoslovak historiography manifested itself basically on two levels. First, it encompassed a wide-reaching change in the perspectives, interpretations, and topics of historical writing. Second, it was carried out primarily by a younger generation of historians, who received the necessary support from a reform-oriented party leadership in accessing archives and acquiring foreign literature. The result of the first aspect was a strong turn to topics in twentieth-century history, and the writing of more or less conventional national history. ${ }^{27}$ The narrative of these reform-oriented Prague Spring historians generally started with the foundation of Czechoslovakia in 1918, stressed the democratic traditions of interwar Czechoslovak communist thought, and culminated in the communist anti-Nazi resistance during World War II and the postwar

23. Jiří Kořalka, "Historiography of the Countries of Eastern Europe: Czechoslovakia", The American Historical Review, 4 (1992), pp. 1026-1040, 1029-1030.

24. For a similar generational clash in Czechoslovak sociology, see Michael Vořǐšek, The Reform Generation: 1960s Czechoslovak Sociology from a Comparative Perspective (Prague, 201 2).

25. Vítězslav Sommer, Angažované dějepisectví. Stranická historiografie mezi stalinismem a reformnim komunismem (1950-1970) [Engaged Historiography: Party Historiography between Stalinism and Reform Communism i 950-1970] (Prague, 201 I), pp. 325-327.

26. Ibid., pp. 344-347.

27. This argument is particularly strongly elaborated in the works of Maciej Górny. See, for example, Maciej Górny, "Die Geschichtswissenschaften in der Volksrepublik Polen, der DDR und der Tschechoslowakei im Vergleich", in Bohumil Jiroušek et al., Proměny diskursu české marxistické historiografie [Changes in the Discourse of Czech Marxist Historiography] (České Budějovice, 2008), pp. 43-63. For another account, see Michal Kopeček, "Historical Studies of Nation-Building and the Concept of Socialist Patriotism in East Central Europe 1956-1970", in Pavel Kolár̆ and Miloš Řezník (eds), Historische Nationsforschung im geteilten Europa 1945-1989 (Cologne, 20I 2), pp. I 2 I-I 36. 
system of the National Front. Less contemporary topics, such as industrialization and the early labour movement, or that of the Hussite rebellion, were, of course, still studied, but they did not enjoy the same state support and interest from younger historians. ${ }^{28}$ Secondly, the rise of this younger generation of scholars pushed their older colleagues (such as Josef Polišenský), who had maintained very intensive contacts with British historiography in the I950s, onto the defensive. Paradoxically, the more Czechoslovak historiography freed itself from its Stalinist traditions and started to emphasize the democratic traditions of Czechoslovak socialism, the more it lost its contacts with the West. Thus, when, in the second part of the I960s, the interpretative frameworks of Czechoslovak historiography were probably most open to the approach and arguments of The Making, there was little interest in the history of early industrialization, let alone in British scholarship in this area. By that time, from an intellectual point of view, seemingly the most suitable for the broader reception of Thompson's work, there was no one to carry it out in Czechoslovakia owing to the strong "nationalization" of historical research.

Meanwhile, Polish historiography proved much more open towards Thompson's work, particularly The Making. This was a result of many factors, some of them reaching back to the interwar period. The high professional standard and international recognition of Polish interwar historiography encouraged many older historians not to depart from some of their pre-World-War-II methodological standpoints. Due to the moral authority of the Church, stemming from its role in World War II, Catholic influence remained valid, and, following Stalin's death in 1956, more orthodox Marxism remained just one of several methodological approaches, without being able to assume the position of a binding paradigm, as was the case in Czechoslovakia. ${ }^{29}$ Thus, some Polish historians were able to follow recent developments in their respective fields in the West, including the publication of The Making, which received attention in Poland very early on. One of the two major Polish historical journals, Przeglad Historyczny [Historical Review], published a detailed review of Thompson's book as early as $1964 .{ }^{30}$ The reviewer praised the extraordinarily wide heuristics and the geographical scope of the book, which comprised not only the prominent industrial centres of England but also smaller towns. He saw The Making primarily within the context of a specific British writing of labour history, and greeted the fact that

28. On the "Prague Spring” historiography, see Sommer, Dëjepisectví, pp. 253-3 I6.

29. For the ambiguous relationship between historiography and Marxist theory in socialist Poland, see Jerzy Topolski, "Polish Historians and Marxism after World War II", Studies in Soviet Thought, 2 (1992), pp. I69-183.

30. Henryk Katz, Review of Thompson's The Making of the English Working Class (London, 1963), Przeglad Historyczny, 4 (1964), pp. 698-701. 
Thompson presented decisive arguments to dismantle the older works of G.D.H. Cole.

However, the most striking feature of the book for the reviewer was the perception of the English working class not as an abstract theoretical structure, but as a particular historical phenomenon, emerging in a certain historical context and forged by real people. Here, the review clearly identified Thompson's main challenge for East-Central European labour history; namely, that the departure from highly structural economic determinism and the perception of the working class as an active subject of its own making had the greatest potential to question some of the main presumptions of local labour historians. The obvious dissonance with existing Marxist-Leninist interpretations, which saw the local working classes as mere objects that emerged from the impersonal structures of industrialization, made it hard to accommodate The Making into any existing communist stream of scholarship. Thus, the reviewer concluded, the work is "extremely suggestive" and "unprecedentedly innovative", and represents "a lasting contribution to the study of class culture". ${ }^{3 \mathrm{I}}$ The reviewer, Henryk Katz, remained one of a very few historians in East-Central Europe who openly expressed the obvious challenge that Thompson's work issued to local scholarship. Thompson's attempt to "humanize" labour history stood in stark contrast to the many writings framed by official Marxism produced all over East-Central Europe in the I950s and at the start of 1960s, which cast the emergence of the local working classes as a depersonalized, objective historical process without paying much attention to the experiences of the actual historical agents. ${ }^{32}$

\section{CLOSING THE DOOR: RECEPTION OF THE MAKING FROM THE 1960 s TO THE FALL OF COMMUNISM}

The suppression of the Prague Spring in 1968 brought about deep and long-lasting changes within the Czechoslovak academic landscape. With the humanities constituting one of the main intellectual hubs of the reform

3. Ibid., p. 70 I.

32. See the following review articles on Poland: Anna Zarnowska, "Geschichte der Arbeiterklasse und der Arbeiterbewegung. Eine Umschau der Forschungsproblematik im letzten Jahrzehnt”, Mitteilungsblatt zur Erforschung der Europäischen Arbeiterbewegung, I3 (1993), pp. 4-40, 4-5. On Czechoslovakia: Milan Myška and Karel Novotný, Přehled literatury o dějinách prümyslu a dělnické tř́dy v českých zemích za léta 1956-1959 [Overview of the Literature on the History of Industry and the Working Class in the Bohemian Lands Published Between 1956 and 1959] (Opava, I96I). On the GDR: Jürgen Reulecke and Peter Friedemann, "Die Historiographie der DDR und die Deutsche Arbeiterbewegung. Zur Entwicklung eines Forschungsschwerpunktes der marxistisch-leninistischen Geschichtsschreibung", in Alexander Fischer and Günther Heydemann (eds), Geschichtswissenschaft in der DDR, Band II: Vor- und Frühgeschichte bis Neuste Geschichte (Berlin, 1990), pp. 519-554. 
movement, university history departments, as well as the respective institutes of the Academy of Sciences, were subjected to ferocious purges. Over I 40 historians were removed, and those who assumed their positions had very limited scope to look for any inspiration behind the Iron Curtain. ${ }^{33}$ Access to Western literature was limited, contacts beyond the Iron Curtain were reserved for a few selected and "ideologically reliable" historians, and the heads of the principal institutes were put under close observation by the party apparatus. Being partly under strong ideological pressure, and partly exerting this pressure themselves, Czechoslovak official historians in the I 970 s and I 980 s gave up on any methodological innovation, let alone look for inspiration from the West, and confined their work to the safe ground of empirical economic history, depicting the history of industrialization more or less as a set of numbers and statistics. ${ }^{34}$

Revisiting some of the main explanatory patterns of the 1950s, the emergence of a unified working class, standing at the forefront of the "emancipatory march of history", was a priori assumed and academic labour history just delivered empirical, often statistical, data to prove the exact time and place in which this happened. Although some of the quantitative methods and arguments paralleled the boom of social history that unfolded within most Western historiographies from the I960s to the I980s, the teleological concept of working class, which made an appearance in history only to march towards its inevitable victory and the establishment of the communist utopia, rendered the orthodox Marxist approach to labour history incompatible with the majority of Western scholarship. ${ }^{35}$

If there were any contacts with the West, they were found among older historians, who had been sidelined from the official historiography in the late I960s but who were occasionally summoned to participate in international projects by Western partners. For example, when, in the mid-r 980 s, a large comparative project on relations between the middle- and working classes in nineteenth-century Europe emerged around the Bielefeld School in West Germany, it found a suitable partner in Czechoslovakia in the person of Jiří Kořalka, who became the main Czechoslovak contributor. ${ }^{36}$ Born in I93 I,

33. For documentation on this process at the time, see Acta Persecutionis: A Document from Czechoslovakia. Presented to the XIVth International Congress of Historical Sciences (San Francisco, 1975).

34. For a typical example of this historiographical production, see Jaroslav Purš, Changes in the Standard of Living and Nutrition of the Working Class in the Czech Lands, 1849-1879 (Prague, 1986).

35. See, for example, Geoff Eley, A Crooked Line: From Cultural History to the History of Society (Ann Arbor, 2005), pp. 25-59. Iggers and Wang, A Global History, pp. $250-269$.

36. Jiři Kořalka, "Arbeiteremanzipation und Bildung in einer aufsteigenden Nationalgesellschaft: Das Beispiel Böhmens", in Jürgen Kocka and Elisabeth Müller-Luckner (eds), Arbeiter und Bürger im 19. Jahrbundert, Varianten ibres Verbältnisses im Europäischen Vergleich (Munich, I986), pp. 65-74. 
Kořalka belonged to the generation of historians who had made their entry into Czechoslovak academia during the mid-i95os and who had helped to shape the local historiography on nineteenth-century labour history throughout the late I950s and I960s. ${ }^{37}$ Despite his exclusion from the official stream of Czechoslovak historiography in the I970s, spending the rest of the communist era in a provincial museum, Kořalka was still able to maintain his contacts with the West, acquired during the previous decades, and to occasionally contribute to international projects. ${ }^{8}{ }^{8}$ Having departed from the official Marxist orthodoxy, Kořalka and some other historians of his generation started to embrace more open approaches to the study of working-class formation. At the same time, they generally kept a focus on material conditions and thus could easily relate to Weberian approaches, which had a lot of currency in the I970s and I980s, particularly in West German social history in the vein of the Bielefeld School. ${ }^{39}$ Therefore, even here, outside the mainstream of orthodox Czechoslovak labour history of the I970s and I980s, Thompsonian ideas could not resonate and were thus practically non-existent.

As already mentioned, historians in Poland recognized the significance of Thompson's work from early on. However, this recognition proved to be short-lived and The Making did not persistently enter the discourse even of the most open historiography of the region, which could boast steady and lively contacts with various currents of Western scholarship. The reasons were partly the same as in Czechoslovakia, yet also partly different. Although the overall intellectual climate of Polish historical scholarship provided probably the best conditions for The Making to be reflected upon, and for some of its main arguments to serve as a starting point for further discussions, the very topic of the book rendered it rather unattractive for Polish scholars. Although Henryk Katz had identified Thompson's work as a "lasting contribution to the study of class culture", it was symptomatic

37. See, in particular, Jiři Kořalka's substantial piece, Vznik socialistického dělnického bnutí na Liberecku [The Emergence of the Socialist Workers' Movement in the Liberec Region] (Liberec, 1956).

38. For more on Jiří Kořalka, see the Festschrift on the occasion of his seventy-fifth birthday: Jiří Pokorný, Luboš Velek, and Alice Velková (eds), Nacionalismus, společnost a kultura ve střední Evropě 19. a 20. století. Pocta Jiř́mu Kořalkovi k 75. Narozeninám / Nationalismus, Gesellschaft und Kultur in Mitteleuropa im 19. und 20. Jahrbundert. Festschrift für Jiřr Kořalka zum 75. Geburtstag (Prague, 2007).

39. On the West German "Bielefeld School”, see Friedrich Lenger, "Historische Sozialwissenschaft': Aufbruch oder Sackgasse?", in Christoph Cornelißen (ed.), Geschichtswissenschaft im Geist der Demokratie. Wolfgang J. Mommsen und seine Generation (Berlin, 2010), pp. I I 5-I 32; Bettina Hitzer and Thomas Welskopp (eds), Die Bielefelder Sozialgeschichte. Klassische Texte zu einem geschichtswissenschaftlichen Programm und seinen Kontroversen (Bielefeld, 2010); and Sonja Asal and Stephan Schlak (eds), Was war Bielefeld? Eine Ideengeschichtliche Nachfrage (Göttingen, 2009). 
that he saw Thompson's book as solely relevant in the context of English labour history. In fact, and rather surprisingly for a socialist country, the established and institutionalized study of the history of work and the working class that was common in England, Czechoslovakia, and many other countries did not exist to such an extent in Poland. ${ }^{4}$ Given the complicated political history of Poland, great investments were made in constructing a Polish postwar national narrative based not on the rise of a working class but on the history of rural emancipation or the role of the urban intelligentsia. ${ }^{4 \mathrm{I}}$ Due to the more limited degree of industrialization in nineteenth-century Poland, and the strong German influence on the Polish industrial landscape, it was hard for Polish historians to accommodate labour history within the general framework both of the emancipatory "forward march of history" and national history in the same way as their Czechoslovak colleagues did. Thus, while Polish historical writing proved very receptive to Western conceptual innovations in the fields of intellectual history or the economic history of rural areas, ${ }^{42}$ the discipline of labour history remained beyond the mainstream of research and methodologically rather conservative. It focused mainly on quantifiable data on workers' material standards and mostly limited its research to the labour force employed in the emerging heavy industries. ${ }^{43}$

Unlike some other regions of the world, where Thompson's magnum opus was echoed in the study of rural popular disturbances and movements, Poland did not see Thompsonian analytical categories being adopted in the fields of rural and agricultural history. ${ }^{44}$ As one of the politically most relevant topics of Polish historiography, it was subjected to much more intensive official policing. Moreover, the research concentrated rather on the national dimensions of Polish rural history, drawing clear lines between the oppressing (German) nobility and the oppressed (Polish-speaking) rural classes. Such an ethnicized framework channelled research towards the formation of a Polish national

\section{Górny, Die Wabrheit ist auf unserer Seite, pp. 171-216.}

4I. For the importance of intellectual history within Polish historiography, see, for example, Denis Svidžkov, Das Zeitalter der Intelligenz. Zur vergleichenden Geschichte der Gebildeten in Europa (Göttingen, 2006), pp. 103-1 38 .

42. See, for the latter, the path-breaking study by Witold Kula, An Economic Theory of the Fendal System: Towards a Model of the Polish Economy I 500-I 800 (London, 1976).

43. See, for example, Gryzelda Missalowa, Studia nad powstaniem Lodzkiego Okregn Przemyslowego I8I5-1870, Vol. II, Klasa robotniczna [Study of the Uprising in the Eódź Industrial Region, I 8 I 5-I 870, vol. II, The Working Class] (Łódź, 1967). Anna Zarnowska, Klasa robotniczna Krolewstwa Polskiego I 870-1914 [The Working Class of the Polish Kingdom, I8701914] (Warsaw, 1974). For a survey from the early i980s, see Anna Zarnowska, "Soziale Prozesse der Entwicklung der Arbeiterklasse an der Wende 19. und 20. Jahrhundert - die polnische Historiographie", in Helmut Konrad (ed.), Soziale Prozesse der Entwicklung der Arbeiterklasse im 19. Jahrhundert (Bibliographie, Historiographie, Methodologie) (Vienna, I982), pp. 417-425.

44. See the classic work by James C. Scott, The Moral Economy of the Peasant: Rebellion and Subsistence in Southeast Asia (Princeton, 1976). 
consciousness in the countryside and left little space for the finer analysis of social stratification of rural communities or of rural riots. ${ }^{45}$

\section{CONCLUSIONS}

Looking at the Czechoslovak and Polish receptions of The Making, we can conclude that this historiographical "volcano" was spotted even behind the Iron Curtain. However, the internal developments of the local historiographies made it difficult for Thompson's work to become a lasting point of reference for local social historians. By the time it appeared, in 1963, the proclaimed (and, in part, actually practiced) communist internationalism of the I950s had already passed its peak. In the i950s and early I960s, British and French Marxist historians were seen as natural allies by many East-Central European colleagues, and their work was sympathetically received. However, the reform-orientation that began to hold sway in the I960s after the dismantling of Stalinism had the paradoxical consequence of gradually turning East-Central European historiographies towards more closed national narratives. This was the case in Czechoslovakia in the mid- to late-I960s, when Czechoslovakia needed to legitimize the Prague Spring reforms by stressing the singularity of the Czechoslovak historical path in the twentieth century, but also in the relatively more open academic environment of Polish historical writing.

Although the content of these emerging national narratives, as well as the national traditions they stressed, differed across East-Central Europe, the ongoing lack of interest in a transnational dialogue transcending the East-West division made it hard for Thompson's work to persistently enter Czechoslovak or Polish historiography. Moreover, Czechoslovak historians, with their long tradition of writing social and labour history, effectively ignored Thompson's work, even when their own perspectives shifted more to E.P. Thompson's New Left positions. Although his constant emphasis on the democratic traditions of English workers and artisans overlapped in many respects with the emerging Prague Spring narrative of Czechoslovak democratic socialism, the limitations of Czechoslovak reform-oriented historians, both in relation to geographical scope and specific time periods, prevented The Making from becoming a significant point of reference. After the suppression of the Prague Spring, the possibilities for reflecting on any Western thought became, by and large, very limited for academically established historians.

45. For a typical example with further notes on the relevant literature, see Jan Molenda, "The Formation of National Consciousness of the Polish Peasants and the Part They Played in the Regaining of Independence by Poland”, Acta Poloniae Historica, 63/64 (I99I), pp. I 2 I-I 48. 
In Poland, the reception of The Making proved to be much more thorough, but also quite short-lived. Thompson's work was spotted practically immediately after its publication, reviewed, and discussed in terms of some of its most innovative approaches and arguments. But the weakness of Polish labour history made it hard to build upon this initially robust reception. Thus, it was placed solely within the context of British historiography, and, as such, greeted as an innovative piece, but with only very limited importance for Polish historical scholarship.

Returning to the Czechoslovak historian Josef Polišenský and his gratitude to the circle of British Marxist historians, who allegedly broadened not only his academic but also musical horizons: Whatever role Western, and predominantly British, Marxism played among East-Central European historians, it is safe to say that it amounted to much more than just promoting rock music. E.P. Thompson's share in this remained quite limited however.

\section{TRANSLATED ABSTRACTS \\ FRENCH - GERMAN - SPANISH}

Rudolf Kučera. En affrontant l'orthodoxie marxiste: le marxisme occidental, The Making et les historiographies communistes de la Tchécoslovaquie et de la Pologne, I948-I990.

Bien que l'impact de l'œuvre de Thompson en dehors du RU ait été reconnu et évoqué à maintes reprises, les manières dont des catégories et des concepts thompsonniens ou plus largement de la pensée marxiste de l'Ouest furent reçus dans les pays de l'ancien bloc de l'Est restent relativement peu claires. Mais si The Making (titre français: La Formation de la classe ouvrière anglaise) n'a jamais été traduite en polonaise, en tchèque ou en slovaque, les historiens des pays de l'Europe centrale et orientale n'étaient pas entièrement coupés des érudits occidentaux. D'importants instituts et universités dans tout le bloc communiste maintenaient des contacts fondamentaux avec des collègues à l'Ouest, et l'œuvre de Thompson était connue parmi certains historiens locaux de l'histoire sociale. Le marxisme de l'Ouest en général et l'œuvre de Thompson en particulier posèrent des défis qu'il fallut relever. Cet article retrace les manières dont des historiens de la Pologne et de la Tchécoslovaquie répondirent à ces défis à la position officielle de l'orthodoxie marxiste. En prenant The Making pour exemple, il met en valeur la réception (ou l'absence de réception) des influences occidentales sur l'érudition locale, et la dynamique de ces confrontations - qu'elles aient été affirmatives ou critiques - en relation avec le paysage politique changeant des pays de l'Europe centrale et occidentale après la Seconde Guerre mondiale. 
Rudolf Kučera. Der marxistischen Orthodoxie trotzen: Westlicher Marxismus, The Making und die kommunistischen Geschichtsschreibungen der Tschechoslowakei und Polens, $1948-1990$.

Der Einfluss, den E.P. Thompsons Werk außerhalb Großbritanniens entfaltet hat, ist oft anerkannt und benannt worden. Dennoch bleibt recht unklar, wie Thompsons Kategorien und Konzepte, sowie allgemeiner die des marxistischen Denkens aus dem Westen, in den Ländern des ehemaligen Ostblocks rezipiert wurden. The Making (deutscher Titel: Die Entstebung der englischen Arbeiterklasse) ist zwar nie ins Polnische, Tschechische oder Slowakische übersetzt worden, doch waren die Historiker Ostmitteleuropas nicht vollends von der westlichen Forschung abgeschnitten. Bedeutende akademische Institute und Universitäten im gesamten Ostblock unterhielten grundlegende Kontakte zu westlichen Kollegen, und einige Sozialhistoriker der Region waren mit Thompsons Werk vertraut. Der Marxismus aus dem Westen, insbesondere Thompsons Werk, brachte Herausforderungen mit sich, denen begegnet werden musste. Der Beitrag zeichnet nach, wie polnische und tschechoslowakische Historiker auf die Infragestellung der offiziellen Position der marxistischen Orthodoxie reagierten. Am Beispiel von The Making wird die Rezeption (oder auch die Nicht-Rezeption) westlicher Einflüsse auf die lokale Forschung untersucht, und es wird der Dynamik dieser Begegnungen - ob affirmativ oder kritisch - vor dem Hintergrund der sich wandelnden politischen Landschaft der ostmitteleuropäischen Länder nach dem Zweiten Weltkrieg nachgegangen.

Übersetzung: Max Henninger

Rudolf Kučera. Retando la ortodoxia marxista: el marxismo occidental, The Making y las historiografías comunistas de Checoslovaquia y Polonia, 1948-I990.

Si bien el impacto de la obra de Thompson más allá del Reino Unido ha sido reconocida y subrayada en numerosas ocasiones, las distintas formas en que las categorías y conceptos thompsonianos, o en sentido más amplio del pensamiento marxista occidental, fueron recibidas en los países que configuraban el bloque oriental todavía permanecen con grandes sombras. Aunque The Making (título español: La formación de la clase obrera en Inglaterra) nunca fue traducido al polaco, al checo o al eslovaco, los historiadores de los países de Europa centro-oriental no estaban desconectados por completo de los investigadores occidentales. Los principales institutos académicos y universidades a lo largo y ancho del bloque comunista mantuvieron contactos básicos con sus colegas en el Oeste, y la obra de Thompson fue conocida entre algunos historiadores sociales locales. El marxismo proveniente del Occidente en general, y la obra de Thompson en particular, plantearon retos que debían de ser enfrentados. En este artículo se perfilan las formas en que los historiadores de Polonia y Checoslovaquia dieron respuesta a los retos planteados a la posición oficial de la ortodoxia marxista. Tomando The Making como ejemplo, se destaca la recepción (o la ausencia de la misma) de las influencias occidentales sobre los estudiosos locales y las dinámicas de tales encuentros -ya fueran coincidentes como discordantes- en el contexto del paisaje político cambiante de los países de la Europa centro-oriental tras la Segunda Guerra Mundial. 